\title{
Effect of Human Capital on Productivity of Non-Life Insurance Line: Evidence from Ethiopian Insurance Corporation
}

\author{
Gemachis Debala Biru \\ College of Business and Economics, PO box. 18, Assosa, Benishangul Gumuz, Ethiopia
}

\begin{abstract}
The purpose of this study was to examine the impact of human capital on productivity of Non-life insurance business in Ethiopia with special reference to Ethiopian Insurance Corporation. The study adopted mixed type of research approach with arrangement of primary data collection via a cross-sectional survey questionnaire and secondary data from financial statement of Ethiopian non-life insurance business. The sample of this study was 95 employees of determined by Yamane's formula and selected using simple random sampling technique. The questionnaires were distributed to 82 employees of EIC and only 60 were completed and returned. The study used regression analysis technique and used STATA software package. The study finding revealed that human capital is positively and significantly affecting productivity in Ethiopian Insurance corporation. Therefore, the study recommends that an Ethiopian Insurance corporation should understand and develop better mechanism in this regard to increase productivity in the company.
\end{abstract}

Keywords: Insurance, Human capital, Non-life insurance, Productivity

DOI: $10.7176 / \mathrm{EJBM} / 13-9-04$

Publication date:May $31^{\text {st }} 2021$

\section{Introduction}

In recent years, an insurance is act as a risk transferring way to provide financial benefit and protection against losses. It offers benefits, income, life and property protection to the insured and their keens, as well as capital accumulation that can be improve desired lifestyle (Apergis and Poufina, 2020 and Biru, 2020). Having this greater insight, the life as well as non-life insurance market has grown rapidly and becoming wide spread at an international level (Mark et.al.,1993). Obviously, an insurance sector plays a vital role in the economy. Therefore, this sector should be profitable. But, in developing countries like Ethiopia an insurance sector is not well developed due to their low amount of productivity and they contribute less $3 \%$ to an economy as whole in comparison to other financial institution. Particularly, an Ethiopian Insurance Corporation is selected among the insurance firms operated in Ethiopia. The rationale for this selection are, an Ethiopian Insurance Corporation is the sole governmental insurance company in Ethiopia. Furthermore, it has a largest market share and employees (more than $83 \%$ ) than other insurance companies. Therefore, this paper investigated the prime effect of human capital on the productivity in an Ethiopian Insurance Corporation with special reference to Life insurance.

\section{Literature Review}

Productivity is defined as output per employee hour and quality as well as it measures how well an organization, individual, industry or countries converts input resources such as labor, materials and machines into goods and services. Furthermore, the productivity is measured by considering increase in performance as when there is less absenteeism, fewer employee leaving early and less breaks; whereas increase in performance can be measured by the number of units produced per employee per hour. Therefore, productivity insurance industry plays in which provide a unique provision of financial service by serving the societies in managing risk. It measures how efficient and state productivity of their domestic output market (Hanna, 2015 and Syverson, 2011).

As per studies of Lentz and Mortensen (2008), about 75 percent of aggregate productivity growth comes from reallocation of inputs (employment in their setup) to innovating firms and about one-third of this comes from entry and exit channels. Furthermore, two-thirds occur as inputs move toward growing firms (and hence innovating firms, as seen through the lens of their model) from firms that lose market share when they fall behind quality frontier.

Product innovation can be aimed at entering new markets, or at refocusing a firm 's efforts toward growing demand segments, as documented in Acemoglu and Linn (2004). Product innovation 's productivity effects have been studied in several recent papers. As touched on above, one of the mechanisms behind IT-based productivity growth (Bartel, et.al., 2007 Acemoglu and Linn, 2004).

Walker (1887) posits that managerial ability is the source of differences in surplus across businesses. The excess of produce which we are contemplating comes from directing force to its proper object by the simplest and shortest ways; from saving all unnecessary waste of materials and machinery; from boldly incurring the expensethe often large expense - of improved processes and appliances, while closely scrutinizing outgo and practicing a thousand petty economies in unessential matters; from meeting the demands of the market most aptly and instantly; and, lastly, from exercising a sound judgment as to the time of sale and the terms of payment. It is on account of 
the wide range among the employers of labor, in the matter of ability to meet these exacting conditions of business success, that we have the phenomenon in every community and in every trade, in whatever state of the market, of some employers realizing no profits at all, while others are making fair profits; others, again, large profits; others, still, colossal profits

Researchers have long proposed that managers drive productivity differences whether sourced in the talents of the managers themselves or the quality of their practices, this is an appealing argument. Managers are conductors of an input orchestra. They coordinate the application of labor, capital, and intermediate inputs. Managers can take a number of key steps toward improving productivity. They should develop productivity measures for all operations. Measurement is the first step in managing and controlling an operation. They should develop methods for achieving productivity improvements, establish reasonable goals for improvement, considers incentives to reward workers for their contribution and measure improvements and publicize them (Kachwala and Bhadra, 2014).

Managers should create the circumstances necessary for the relationship building needed for knowledge creation by providing time, space, attention, and opportunities. Management can provide physical space such as meeting rooms, cyberspace such as a computer network, or mental space such as common goals to foster interactions. Moreover, it was found that when organizations used their preserved knowledge through structured periodic activities, they intensified their knowledge (Katila and Ahuja, 2002). Managerial ability is the source of differences in surplus across businesses. More intense competition in the firm 's market is positively correlated with best-practice management. Additionally, management practice scores are lower when the firm is familyowned and primogeniture determined the current CEO 's succession i.e., he/she is the eldest son of the firm 's founder. Interestingly, primogeniture 's tie to productivity is not about family ownership. In fact, family ownership in isolation is positively correlated with good management (Bloom and Reenen, 2007).

\section{Method}

This study shaped with mixed research approach. The approach to this study requires a wide collection of opinions on the subject matter and ways of achieving this is through administration of questionnaires. Each item on the standardized questionnaire shall be scored using a five-point Likert scale. The scale was ranked ranging from $=$

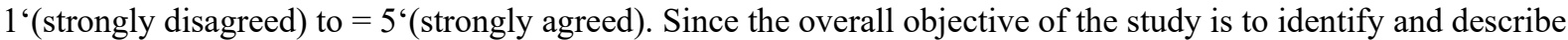
the productivity of insurance companies, the case of Ethiopian Insurance corporation, descriptive study particularly survey method of research is essentially used as a main method of research to accomplish this objective, primary data was secured through the use of questionnaires.

The target population of this study is professional employees and managers of Ethiopian Insurance Corporation who have experience of more than or equal to one year worked at head quarter Ethiopian Insurance Corporation. From the target population the researcher selecting a representative of sample of the population of the employees was found to be feasible with the designed criteria used by the researcher. As far as sampling is concerned, the researcher used random sampling technique to determine sample size of employees working in EIC at head office, excluding guards, drivers and janitors was 125 permanents. The sample size is being determined by using Yemane (1964) formula as follows.

$$
\mathrm{n}=\mathrm{N} / \mathbf{1}+\mathrm{Ne}^{2}
$$

Where; $\mathbf{n}=$ number of samples, $\mathrm{N}=$ total population $\mathbf{e}=$ is the error term, which is $5 \%$ (i.e. at $95 \%$ confidence level). Therefore, the sample size is computed as:

$$
\begin{aligned}
& n=125 / 1+125(0.05)^{2} \\
& n=95 \text { were used as sample size for this study. }
\end{aligned}
$$

The collected data was analyzed quantitatively and qualitatively. The collected data was summarized, organized, tabulated using Stata Version 14. Furthermore, the data was analyzed quantitatively by using descriptive statistics and correlation. The correlation analysis was used to exhibit the nexus between the dependent variable which is productivity and an independent variable which is human capital. During the data analysis, the reliability of questionnaire was tested by using Cronbach 's alpha coefficient on Stata 14.2.

Table 1: Test for reliability through test scale mean

\begin{tabular}{|l|l|}
\hline Average inter item covariance: & 0.09029 \\
\hline Number of items in the scale: & 40 \\
\hline Scale reliability coefficient: & $\mathbf{0 . 7 9}$ \\
\hline
\end{tabular}

\section{Results}

The research finding presents the discussion on the effect of human capital on the productivity Ethiopian insurance corporation presented in table 1 below. 
Table 1: Descriptive statics summary

\begin{tabular}{|l|l|l|}
\hline & Productivity & Human Capital \\
\hline Mean & 1.73 & 2.34 \\
\hline Median & 0.46 & 0.91 \\
\hline Maximum & 0.22 & 4.28 \\
\hline Minimum & -0.45 & 0.01 \\
\hline Std. Dev. & 0.05 & 0.69 \\
\hline Observations & 60 & 60 \\
\hline
\end{tabular}

Variance Inflation Factor

Table 2: Variance Inflation Factor

\begin{tabular}{|l|l|l|}
\hline Variable & VIF & $1 /$ VIF \\
\hline HC & 1.2 & 0.84 \\
\hline Mean VIF & 1.2 & \\
\hline
\end{tabular}

Source: Primary data as calculated by Stata.

As indicated in different literature, when the variance inflation factor (VIF) is equal to one it indicated that, there is no relationship between dependent variable and independent variables and if VIF is greater than 10, then, there will be a multicollinearity problem. Therefore, this study indicates that, the mean of VIF from the table below lies between 1 and 10 which is acceptable

\section{Regression analysis for primary and secondary data}

Regression analysis for primary data

In the current study, the researcher employed 8 questionnaires to examine and assess to extent the human capital influence the productivity of Ethiopian government owned insurance Corporation. The dependent variable productivity was measured by four items (Question No. 9, 10, 11 and 12). Particularly, an independent variable which is human capital related data were collected from employees and measured by eight items (Question No.1, 2, 3, 4, 5, 6, 7, and 8). The data was then analyzed on quantitative basis using Pearson 's correlation, linear regression analysis and descriptive statistics.

Table 3: Human capital versus productivity

\begin{tabular}{|c|c|c|c|c|c|c|c|c|c|c|}
\hline \multirow{2}{*}{$\begin{array}{l}\text { Item } \\
\text { No }\end{array}$} & \multirow[b]{2}{*}{ Variable } & \multirow[t]{2}{*}{ Obs } & \multirow[t]{2}{*}{ Mean } & \multirow[t]{2}{*}{ Std. Dev. } & \multicolumn{2}{|c|}{$\begin{array}{l}\text { DA(1 } \\
\& 2)\end{array}$} & \multicolumn{2}{|l|}{ UD } & \multicolumn{2}{|c|}{$\begin{array}{l}\mathrm{A \& SA}(4 \\
\text { and 5) }\end{array}$} \\
\hline & & & & & No. & $\%$ & No. & $\%$ & No. & $\%$ \\
\hline 1 & $\begin{array}{l}\text { Productivity is measurement is } \\
\text { developed by existing human } \\
\text { capital/management of the company }\end{array}$ & 60 & 3.03333 & 1.007879 & 15 & 25 & 24 & 40 & 21 & 35 \\
\hline 2 & $\begin{array}{l}\text { Different techniques are used by } \\
\text { management of the Ethiopian } \\
\text { insurance corporation achieve } \\
\text { productivity. }\end{array}$ & 60 & 4.06667 & 0.6342396 & 3 & 5 & 1 & 1.7 & 56 & 93.3 \\
\hline 3 & $\begin{array}{l}\text { The Ethiopian insurance corporation } \\
\text { Management established goals for } \\
\text { productivity improvement. }\end{array}$ & 60 & 3.43333 & 1.15519 & 16 & 26.7 & 0 & 0 & 44 & 73.3 \\
\hline 4 & $\begin{array}{l}\text { The workers receive incentive as a } \\
\text { reward for their contribution }\end{array}$ & 60 & 4.35 & 0.4809947 & 0 & 0 & 0 & 0 & 60 & 100 \\
\hline 5 & $\begin{array}{l}\text { Productivity improvements is } \\
\text { measured and publicize by an } \\
\text { Ethiopian Insurance corporation. }\end{array}$ & 60 & 1.55 & 0.594466 & 57 & 95 & 3 & 5 & 0 & 0 \\
\hline 6 & $\begin{array}{l}\text { Management supports will create } \\
\text { conducive working environment }\end{array}$ & 60 & 2.73333 & 1.376149 & 27 & 45 & 7 & 11.7 & 26 & 43.3 \\
\hline 7 & $\begin{array}{l}\text { Corporation has a democratic style } \\
\text { of leadership by the human capital }\end{array}$ & 60 & 3.01667 & 1.157022 & 24 & 40 & 5 & 8.3 & 31 & 51.7 \\
\hline 8 & $\begin{array}{l}\text { Product innovation } \\
\text { productivity to increase } \\
\text { customers. }\end{array}$ & 60 & 3.2 & 1.204511 & 17 & 28.3 & 8 & 13.3 & 35 & 58.4 \\
\hline & Human Capital & 60 & 3.17292 & 0.4324568 & & & & & & \\
\hline
\end{tabular}

\section{Source: Primary data}

As exhibited in table 4 above, management developed productivity measure by $40 \%$ for all operation, majority 
of the worker. On the other hand, $35 \%$ of the respondents agreed and $25 \%$ of them disagreed. Further, $93.3 \%$ of the respondents agreed and responded that management should develop human capital for achieving productivity improvement. In addition, $73.3 \%$ agreed that management established goal for productivity improvement. Without exception, all employees under sample agreed that Management considers incentive plans to reward workers for their contribution. On the variable whether management measures productivity improvements and publicize them, the result indicated that almost all (95\%) disagreed. $43.3 \%$ of the respondents agreed that management supports to have good working environment. Considerable percentage $(45 \%)$ also disagreed to this fact might indicate the management to further investigate the case. More than half $(51.7 \%)$ of the respondents also confirmed that management has democratic style of leadership.

In line with product innovation, the firm 's productivity can be enhanced with patents that the innovation firms can gain as a result of new invention that can help the firm as intangible capital like that of experience, technological and know-how.

Accordingly, table 3 above, it can be seen that $58.4 \%$ of the employees agreed that product innovation enhance the productivity of a company. This implies that the management should concentrate on product innovation, create a conducive environment and transparent in all aspects to its employees.

Regression analysis for secondary data

Table 5: Regression Table

\begin{tabular}{|l|l|l|l|l|l|l|}
\hline Pdty & Coef. & Std. Err. & t & P>t & [95\% Conf. & Interval] \\
\hline & & & & & & \\
\hline MGP & .3033875 & 0.102027 & 2.97 & $\mathbf{0 . 0 0 4}$ & .0987473 & 0.5080278 \\
\hline cons & -.0362609 & 0.8710584 & -0.04 & 0.967 & -1.783383 & 1.710861 \\
\hline
\end{tabular}

\section{Source: Primary source generated by STATA}

Regression Coefficient Analysis of the model indicates $\beta 1=0.3034, \mathrm{~T}=2.97$ and $\mathrm{P}=0.004$, which indicates that the human capital it has a positive significant effect on productivity with $5 \%$ significance. The P-value for human capital shows below $0.05 \mathrm{y}$ and the study finding revealed that human capital is positively and significantly affecting productivity in EIC. The finding of this study is consistent with finding of Feyera (2012) and Leblebici (2012). Hence the organization needs to understand and develop mechanism in this regard to increase productivity in the company. Furthermore, the regression summary model implies that an adjusted R square value of 0.2737 signifying that independent variables of the study explain about $27.4 \%$ of the variation in the level of dependent variable and the rest $72.6 \%$ variation is explained by other variables not included in the model or is unexplained by the independent variables. management practice.

Correlation Analysis

Table 6: Correlation analysis between dependent and independent Variable

\begin{tabular}{|l|l|l|}
\hline & Pdty & Human Capital \\
\hline Pdty & 1 & \\
\hline MGP & 0.274 & 1 \\
\hline
\end{tabular}

\section{Source: Primary data and Stata}

Table: 16 presents the result of the correlation analysis of Productivity in relation human capital can take a range of values from +1 to 0 indicates a perfect positive linear relationship

This implies that human capital related variables has strong relationship with the productivity of an Ethiopian Insurance corporation.

\subsection{Conclusion and Recommendation}

This study assesses the relationship between productivity and Human capital in an Ethiopian insurance sector with special reference to non-life insurance business. In order to conduct an analysis, only one dependent and independent variable, productivity and human capital were used respectively. As indicated in analysis part, the study finding revealed human capital are positively and significantly related to productivity in Ethiopian Insurance Corporation particularly the non-life insurance business. This implies that the insurance corporation should develop better and effective human capital to embrace productivity of non-life insurance business.

Based on the conclusion reached above, the study recommends that an Ethiopian insurance corporation, nonlife insurance business line should improve its productivity via creation of better trained human power through facilitating conducive working environment.

\section{References}

Apergis, N., \& Poufinas, T. (2020). The role of insurance growth in economic growth: Fresh evidence from a panel 
of OECD countries. The North American Journal of Economics and Finance, 53, 101217.

Acemoglu, D., \& Linn, J. (2004). Market size in innovation: theory and evidence from the pharmaceutical industry. The Quarterly journal of economics, 119(3), 1049-1090.Biru, G. D. (2017). profitability determinants in the insurance sector in Ethiopia: a panel evidence on non-life insurance (Doctoral dissertation, Addis Ababa University Addis Ababa, Ethiopia).

Browne, M. J., \& Kim, K. (1993). An international analysis of life insurance demand. Journal of Risk and Insurance, 616-634.

Bartel, A., Ichniowski, C., \& Shaw, K. (2007). How does information technology affect productivity? Plant-level comparisons of product innovation, process improvement, and worker skills. The quarterly journal of Economics, 122(4), 1721-1758.

Bloom, N., Dorgan, S., Dowdy, J., \& Van Reenen, J. (2007). Management practice and productivity: Why they matter. Management Matters, 10.Syverson, (2010), what determines productivity?

Feyera. (2016), Productivity in footwear and garment sector in Addis Ababa, MBA thesis Addis Ababa University.

Hanna, M. D. 2015. Determinants of insurance companies' profitability in Ethiopia. Master's thesis. Addis Ababa University, Ethiopia.

Kachwala, T., \& Bhadra, A. (2014). Challenges in productivity measurements \& improvements in service organizations. EXCEL International Journal of Multidisciplinary Management Studies, 4(4), 104-

Katila, R., \& Ahuja, G. (2002). Something old, something new: A longitudinal study of search behavior and new product introduction. Academy of management journal, 45(6), 1183-1194.

Leblebici, D. (2012). Impact of workplace quality on employee's productivity: case study of a bank in Turkey. Journal of Business Economics and Finance, 1(1), 38-49.

Lentz, R., \& Mortensen, D. T. (2008). An empirical model of growth through product innovation. Econometrica, 76(6), 1317-1373.

Syverson, C. (2011). What determines productivity?. Journal of Economic literature, 49(2), 326-65.

Walker, Francis A. (1887). The Source of Business Profits.l Quarterly Journal of Economics, 1(3): 265-288. 